УДК 581.143.6:633.15

\author{
К. В. Деркач
}

Інститут сільського господарства степової зони НААН Украӥни

\title{
ДИНАМІКА КАЛУСОГЕНЕЗУ В КУЛЬТУРІ IN VITRO У ГЕНОТИПІВ КУКУРУДЗИ ЗАРОДКОВОЇ ПЛАЗМИ ЛАНКАСТЕР
}

Оцінено лінії кукурудзи зародкової плазми Ланкастер відносно здатності зберігати морфогенний потенціал калусів за тривалого культивування. Здатність до тривалого морфогенного калусогенезу генотипічно зумовлена та довше залишається високою у ліній, які належать до підплазми Mo17/Oh43. Визначено лінію підплазми Oh43, яка може слугувати базовою в цій підплазмі для тривалого культивування калусів зі збереженням їх морфогенності. Отримано рослини-регенеранти 3 культивованих тривало калусів. Визначено лінії, перспективні для використання у біотехнологічноселекційних програмах.

\author{
Е. В. Деркач
}

Институт сельского хозяйства степной зоны НААН Украины

\section{ОЦЕНКА ДИНАМИКИ КАЛЛУСОГЕНЕЗА В КУЛЬТУРЕ IN VITRO ГЕНОТИПОВ КУКУРУЗЫ ЗАРОДЫШЕВОЙ ПЛАЗМЫ ЛАНКАСТЕР}

\begin{abstract}
Оценены линии кукурузы зародышевой плазмы Ланкастер по отношению к способности сохранять морфогенный потенциал каллусов при длительном культивировании. Способность к продолжительному морфогенному каллусогенезу генотипически обусловлена и дольше остается высокой у линий, которые относятся к подплазме Мo17/Oh43. Выявлена линия подплазмы Оh43, которая может служить базовой в этой подплазме для длительного культивирования каллусов с сохранением их морфогенности. Получены растения-регенеранты из длительно культивируемых каллусов. Определены линии, перспективные для использования в биотехнологически-селекционных программах.
\end{abstract}

K. V. Derkach

Institute of Agriculture of Steppe Zone of NAAS of Ukraine

\section{ESTIMATION OF CALLUSOGENESIS DYNAMICS \\ IN THE MAIZE CULTURE OF THE LANCASTER GERM PLASM GENOTYPES IN VITRO}

The ability of the maize inbred lines of the Lancaster germ plasm to maintain morphogenic potential of the callus under long cultivation has been estimated. The capability to long-term morphogenic callusogenesis is genotypically determined and longer in the Mo17/Oh43 subplasm line. The line of Oh43 subplasm may be the base for the long-continued cultivation of morphogenic calluses. Regenerated plants from the long-continued cultivated calluses were obtained. Promising inbreds for usage in biotechnology and breeding programs were identified.

\section{Вступ}

Зародкова плазма Ланкастер - одна $з$ перспективних у селекційному відношенні зародкових плазм кукурудзи в Україні. Лінії зародкової плазми Ланкастер в основному

(C) К. В. Деркач, 2012 
належать до середньостиглої та середньопізньої груп стиглості, проте їх інтенсивно використовують для створення скоростиглих генотипів кукурудзи, у селекції на абіотичну стійкість та як донори високої комбінаційної здатності $[2 ; 5]$.

Поєднання методів біотехнології та селекції дозволяє дещо полегшити та прискорити процеси з удосконалення генотипів кукурудзи. Зокрема, використання методу культури клітин in vitro, який включає в себе етапи калусогенезу та регенерації, сприяє розширенню різноманіття вихідного селекційного матеріалу.

Калуси, які утворюються в процесі культивування in vitro незрілих зародків кукурудзи, поділяють на калуси типу I і типу II. Калуси типу I - компактні новоутворення, які ростуть повільно та регенерують шляхом соматичного ембріогенезу та пагоневого органогенезу. Тривалість їх вирощування в культурі та регенераційна здатність обмежена декількома місяцями. Калуси типу II - крихка ембріонна тканина, яка росте швидко і яку можна підтримувати в культурі до двох років [6; 7].

A. Manivannan et al. [9; 10] характеризують калус типу I як компактний і органогенний, а калус типу II - крихкий і ембріогенний. Відмічено, що калус типу II володіє вищою регенераційною здатністю, ніж калус типу I. Калуси типу II використовуються для генетичної трансформації [11], для отримання стійких до абіотичних факторів генотипів [8], а також із метою отримання сомаклональних варіантів, оскільки у міру старіння тканини в ній накопичуються генетичні мутації [6].

Тривале збереження морфогенності культивованих калусів дає можливість відмовитися від використання штучного клімату.

У роботі [4] проведено оцінку калусогенного потенціалу ліній кукурудзи зародкової плазми Ланкастер на 30-ту добу культивування in vitro. Мета даної роботи оцінка динаміки калусогенного потенціалу в культурі in vitro у генотипів кукурудзи гетерозисної групи Ланкастер та визначення тривалості збереження морфогенного потенціалу даних генотипів.

\section{Матеріал і методи досліджень}

Матеріалом дослідження виступали 10 ліній кукурудзи зародкової плазми Ланкастер: лінії ДК267, ДК212, ДК6080, ДК420-1 (підплазми Oh43), ДК633/266, ДК298 (підплазми Мo17/Oh43), ДК633 (підплазми Мо17), ДК3070 (підплазми Мo17/O92), ДК236 (підплазми Mo17/F2) і ДК633/325 (підплазми Мо17/Міндзенпуста). Як стандарт використовували лінію Chi31, яка належить до екзотичної зародкової плазми (підплазми Chi31) та широко використовується у біотехнологічних дослідженнях.

Донорні рослини вирощували у польових умовах за загальноприйнятою методикою польового досліду. Ізольовані незрілі зародки довжиною 1,0-1,5 мм на 10-12-ту добу після штучного запилення експлантували на живильне середовище N6 із додаванням 100 мг/л гідролізату казеїну, 100 мг/л мезоінозиту, 690 мг/л $L$-проліну, 30 г/л сахарози, 10 мг/л нітрату срібла, 1 мг/л 2,4-дихлорфеноксіоцтової кислоти та 0,1 мг/л абсцизової кислоти. Культивування проводили у темряві при $+25 \ldots+27^{\circ} \mathrm{C}$. На 150 -ту добу культивування калуси розділяли на приблизно однакові за розмірами шматочки (приблизно 1,0-1,5 см) та висаджували на модифіковані за допомогою 100 мг/л гідролізату казеїну, 100 мг/л мезоінозиту, 690 мг/л $L$-проліну, 20 г/л сахарози середовища MS із різним вмістом 6-бензиламінопурину (6-БАП) (0; 0,1 та 1,0 мг/л).

Результати культивування реєстрували на 30, 60, 75, 90 та 120-ту добу від експлантації зародків. Частоти утворення морфогенних калусів, калусів типів I і II розраховували як процентне відношення зародків із певним типом реакції до загальної кількості культивованих зародків. Статистичну обробку даних проводили згідно 3 [1]. 
Дані у таблицях наведені у вигляді $\bar{x} \pm m t_{0.05}$, де $x$ - середнє арифметичне значення показника, $m$ - похибка середнього арифметичного, $t_{0,05}$ - критерій Стьюдента за рівня значущості 0,05 .

\section{Результати та їх обговорення}

Морфогенний потенціал культивованих ліній протягом досліджуваного періоду культивування знижується (табл.). Це стосується ліній, що проявили свій калусогенний потенціал на 30 та 60-ту добу культивування. Найбільший морфогенний потенціал на 120-ту добу культивування зафіксовано у лінії ДК298 (44,4%) підплазми Mo17/Oh43, тоді як інша лінія даної підплазми (ДК633/266) характеризувалася значно нижчим рівнем морфогенного калусогенезу (23,2 \%). Серед ліній підплазми Oh43 вища частота утворення морфогенних калусів на 120 -ту добу культивування відмічалася в лінії ДК267 (25,0 \%). Лінії ДК212, ДК6080 та ДК420-1 даної підплазми характеризувалися значно нижчим рівнем морфогенності (2,0-5,2 \%).

Лінії, які проявили свій калусогенний потенціал лише на 60-ту добу культивування, на 120-ту добу культивування мали показники частоти утворення морфогенних калусів на рівні 0-9,3\%. Лінія ДК236 втратила свою морфогенність вже на 90-ту добу культивування. Лінія-стандарт Chi31 на 120-ту добу культивування відзначалася морфогенним калусогенезом на рівні 11,2 \%. Незважаючи на те, що калуси типу I не здатні до тривалого культивування [6; 7], лінії ДК267, ДК298, ДК633, ДК3070, ДК633/325 та Chi31 на 120-ту добу культивування продовжували демонструвати калуси типу І. Лінія ДК236 не утворила калуси типу I взагалі. У лінії ДК6080 відмічено утворення калусу типу I на 60-ту добу культивування з лише дещо набухлого на 30-ту добу культивування незрілого зародка, хоча вже через 30 діб даний експлант перетворився на калус типу II.

Протягом досліджуваного періоду культивування відбувалося зниження значень частоти утворення морфогенних калусів у результаті переходу їх у неморфогенні, а також частоти утворення калусів типу I у результаті переходу їх у калуси типу II чи неморфогенні. Калуси типу II також демонстрували перехід у неморфогенні калуси.

Відомо, що формування калусів типу II відмічене у вужчому колі генотипів, ніж калусів типу I [6], а також що частота їх утворення нижча, ніж калусів типу I [9; 10]. Отримані на 30-ту добу культивування дані в переважній більшості свідчать про зворотне. Тож здатність до утворення калусів типу I чи II визначається генотипічно та дане співвідношення може бути змінене шляхом оптимізації складу середовища культивування. Обране для калусогенезу середовище рекомендовано використовувати для тривалого культивування ліній ДК298, ДК267 та ДК633/266.

Висаджені на 150-ту добу культивування на середовища регенерації калуси характеризувалися низькою регенераційною здатністю. Лише 3 з 11 ліній (ДК420-1, ДК298 та Chi31) проявили свій регенераційний потенціал. Лінія ДК420-1 (1 випадок регенерації на 233 шматочки калусів) характеризувалася ембріогенезом, лінія ДК298 (6 випадків регенерації на 712 шматочків калусів) - органогенезом, а лінія Chi31 - органогенезом (14 випадків регенерації) та ембріогенезом (2 випадки регенерації на 246 шматочків калусів). Лінії ДК420-1 та ДК298 регенерували лише на середовищі з 0,1 мг/л 6-БАП, лінія Chi31 на всіх варіантах живильного середовища. Зі збільшенням тривалості перебування клітин у культурі in vitro сомаклональна мінливість зростас [3]. Разом із цим різко зменшується регенераційна здатність калусних тканин. Отримані нами дані підтверджують це. Низький регенераційний потенціал ліній, окрім сомаклональної мінливості, можливо, пов'язаний 3 недосконалістю складу живильного середовища. 
Динаміка калусогенезу ліній кукурудзи зародкової плазми Ланкастер і екзотичної зародкової плазми Chi31

\begin{tabular}{|c|c|c|c|c|c|c|c|}
\hline Генотип & Плазма & $\begin{array}{c}\text { Під- } \\
\text { плазма }\end{array}$ & $\begin{array}{c}\text { Кількість } \\
\text { культивованих } \\
\text { зародків, шт. }\end{array}$ & $\begin{array}{c}\text { Діб } \\
\text { у куль- } \\
\text { турі } \\
\end{array}$ & \begin{tabular}{|c|} 
Частота утворення \\
морфогенних \\
калусів, \% \\
\end{tabular} & \begin{tabular}{|c} 
Частота утво- \\
рення калусів \\
типу I, \% \\
\end{tabular} & \begin{tabular}{|c|} 
Частота утво- \\
рення калусів \\
типу II, \% \\
\end{tabular} \\
\hline \multirow{5}{*}{ ДК267 } & \multirow{5}{*}{$\begin{array}{c}\text { Лан- } \\
\text { кастер }\end{array}$} & \multirow{5}{*}{ Oh43 } & \multirow{5}{*}{452} & 30 & \begin{tabular}{|l|}
$71,46 \pm 4,25$ \\
\end{tabular} & $67,92 \pm 4,40$ & $3,54 \pm 1,74$ \\
\hline & & & & 60 & $49,56 \pm 4,71$ & $45,13 \pm 4,69$ & $4,42 \pm 1,94$ \\
\hline & & & & 75 & $48,45 \pm 4,71$ & $43,14 \pm 4,66$ & $5,31 \pm 2,11$ \\
\hline & & & & 90 & $48,23 \pm 4,71$ & $15,93 \pm 3,45$ & $32,30 \pm 4,40$ \\
\hline & & & & 120 & $25,00 \pm 4,08$ & $1,55 \pm 1,16$ & $23,45 \pm 3,99$ \\
\hline \multirow{5}{*}{ ДК212 } & \multirow{5}{*}{$\begin{array}{c}\text { Лан- } \\
\text { кастер }\end{array}$} & \multirow{5}{*}{ Oh43 } & \multirow{5}{*}{268} & 30 & $40,67 \pm 6,01$ & $13,81 \pm 4,22$ & $26,87 \pm 5,43$ \\
\hline & & & & 60 & $11,19 \pm 3,86$ & 0 & $11,19 \pm 3,86$ \\
\hline & & & & 75 & $10,07 \pm 3,68$ & 0 & $10,07 \pm 3,68$ \\
\hline & & & & 90 & $5,22 \pm 2,72$ & 0 & $5,22 \pm 2,72$ \\
\hline & & & & 120 & $5,22 \pm 2,72$ & 0 & $5,22 \pm 2,72$ \\
\hline \multirow{5}{*}{ ДК6080 } & \multirow{5}{*}{$\begin{array}{c}\text { Лан- } \\
\text { кастер }\end{array}$} & \multirow{5}{*}{ Oh43 } & \multirow{5}{*}{186} & 30 & $37,63 \pm 7,12$ & 0 & $37,63 \pm 7,12$ \\
\hline & & & & 60 & $3,23 \pm 2,60$ & $0,54 \pm 1,08$ & $2,69 \pm 2,38$ \\
\hline & & & & 75 & $3,23 \pm 2,60$ & 0 & $3,23 \pm 2,60$ \\
\hline & & & & 90 & $3,23 \pm 2,60$ & 0 & $3,23 \pm 2,60$ \\
\hline & & & & 120 & $3,23 \pm 2,60$ & 0 & $3,23 \pm 2,60$ \\
\hline \multirow{5}{*}{ ДК420-1 } & \multirow{5}{*}{$\begin{array}{c}\text { Лан- } \\
\text { кастер }\end{array}$} & \multirow{5}{*}{ Oh43 } & \multirow{5}{*}{199} & 30 & $30,15 \pm 6,52$ & $2,51 \pm 2,22$ & $27,64 \pm 6,36$ \\
\hline & & & & 60 & $2,01 \pm 1,99$ & $1,01 \pm 1,42$ & $1,01 \pm 1,42$ \\
\hline & & & & 75 & $2,01 \pm 1,99$ & $1,01 \pm 1,42$ & $1,01 \pm 1,42$ \\
\hline & & & & 90 & $2,01 \pm 1,99$ & 0 & $2,01 \pm 1,99$ \\
\hline & & & & 120 & $2,01 \pm 1,99$ & 0 & $2,01 \pm 1,99$ \\
\hline \multirow{5}{*}{ ДК633/266 } & & & & 30 & $84,60 \pm 3,69$ & $5,48 \pm 2,33$ & $79,11 \pm 4,16$ \\
\hline & & & & 60 & $35,51 \pm 4,90$ & $3,13 \pm 1,78$ & $32,38 \pm 4,79$ \\
\hline & кастер & Oh43 & 383 & 75 & $32,90 \pm 4,81$ & $3,13 \pm 1,78$ & $29,77 \pm 4,68$ \\
\hline & & & & 90 & $26,11 \pm 4,49$ & 0 & $26,11 \pm 4,49$ \\
\hline & & & & 120 & $23,24 \pm 4,32$ & 0 & $23,24 \pm 4,32$ \\
\hline & & & & 30 & $78,49 \pm 4,27$ & $34,68 \pm 4,94$ & $43,82 \pm 5,15$ \\
\hline & & & & 60 & $69,62 \pm 4,78$ & $30,91 \pm 4,80$ & $38,71 \pm 5,06$ \\
\hline ДК298 & Кастер & Oh43 & 372 & 75 & $56,45 \pm 5,15$ & $25,27 \pm 4,51$ & $31,18 \pm 4,81$ \\
\hline & & & & 90 & $53,76 \pm 5,18$ & $8,87 \pm 2,95$ & $44,89 \pm 5,16$ \\
\hline & & & & 120 & $44,35 \pm 5,16$ & $0,54 \pm 0,76$ & $43,82 \pm 5,15$ \\
\hline & & & & 30 & 0 & 0 & 0 \\
\hline & & & & 60 & $13,71 \pm 3,16$ & $8,44 \pm 2,56$ & $5,27 \pm 2,06$ \\
\hline ДК633 & Лан- & Mo17 & 474 & 75 & $12,66 \pm 3,06$ & $6,75 \pm 2,31$ & $5,91 \pm 2,17$ \\
\hline & & & & 90 & $9,28 \pm 2,67$ & $1,69 \pm 1,18$ & $7,59 \pm 2,44$ \\
\hline & & & & 120 & $9,28 \pm 2,67$ & $1,48 \pm 1,11$ & $7,81 \pm 2,47$ \\
\hline & & & & 30 & 0 & 0 & 0 \\
\hline & & & & 60 & $12,44 \pm 4,76$ & $12,44 \pm 4,76$ & 0 \\
\hline ДК3070 & кастер & $\mid \begin{array}{c}10101 / 109 \\
2\end{array}$ & 193 & 75 & $8,81 \pm 4,09$ & $8,81 \pm 4,09$ & 0 \\
\hline & & & & 90 & $3,63 \pm 2,70$ & $3,63 \pm 2,70$ & 0 \\
\hline & & & & 120 & $3,63 \pm 2,70$ & $2,59 \pm 2,29$ & $1,04 \pm 1,46$ \\
\hline & & & & 30 & 0 & 0 & 0 \\
\hline & & & & 60 & $1,35 \pm 1,09$ & 0 & $1,35 \pm 1,09$ \\
\hline ДК236 & Лан- & $\begin{array}{l}\text { Nio1// } \\
\text { F? }\end{array}$ & 445 & 75 & $1,35 \pm 1,09$ & 0 & $1,35 \pm 1,09$ \\
\hline & & & & 90 & 0 & 0 & 0 \\
\hline & & & & 120 & 0 & 0 & 0 \\
\hline & & & & 30 & 0 & 0 & 0 \\
\hline & & Mo17/ & & 60 & $9,36 \pm 2,52$ & $7,49 \pm 2,28$ & $1,87 \pm 1,17$ \\
\hline ДК633/325 & $\begin{array}{l}\text { Кан- } \\
\text { кастер }\end{array}$ & Мінд- & 534 & 75 & $6,74 \pm 2,17$ & $6,74 \pm 2,17$ & 0 \\
\hline & & зенпуста & & 90 & $3,93 \pm 1,68$ & $0,94 \pm 0,83$ & $3,00 \pm 1,48$ \\
\hline & & & & 120 & $2,81 \pm 1,43$ & $0,94 \pm 0,83$ & $1,87 \pm 1,17$ \\
\hline & & & & 30 & $59,20 \pm 4,52$ & $19,66 \pm 3,66$ & $39,53 \pm 4,50$ \\
\hline & & & & 60 & $15,43 \pm 3,33$ & $6,34 \pm 2,24$ & $9,09 \pm 2,65$ \\
\hline Chi31 & Екзо- & Chi31 & 473 & 75 & $13,32 \pm 3,13$ & $5,92 \pm 2,17$ & $7,40 \pm 2,41$ \\
\hline & & & & 90 & $11,84 \pm 2,97$ & $4,44 \pm 1,90$ & $7,40 \pm 2,41$ \\
\hline & & & & 120 & $11,21 \pm 2,90$ & $1,27 \pm 1,03$ & $9,94 \pm 2,75$ \\
\hline
\end{tabular}




\section{Висновки}

Здатність до тривалого культивування in vitro зі збереженням морфогенного потенціалу у ліній кукурудзи генотипічно зумовлена. Проведено оцінку динаміки калусогенезу 10 ліній кукурудзи зародкової плазми Ланкастер та лінії-стандарту Chi31. Показано можливість тривалого збереження морфогенності культивованих калусів. Підплазма Mo17/Oh43 довше за інші досліджені підплазми здатна до збереження морфогенного потенціалу калусів. Серед ліній - представників підплазми Oh43 відзначено ДК267 як лінію з тривалим збереженням морфогенності культивованих калусів. Рекомендовано ДК298, ДК267 та ДК633/266 як лінії із тривалим збереженням морфогенності до застосування у біотехнологічно-селекційних програмах за умови підбору оптимального середовища регенерації.

\section{Бібліографічні посилання}

1. Атраментова Л. О. Статистичні методи в біології / Л. О. Атраментова, О. М. Утевська. - Х. : ХНУ ім. В. Н. Каразіна. $-2007 .-288$ с.

2. Боденко Н. А. Добір та оцінка вихідного матеріалу на посухо- та жаростійкість для селекції середньостиглих гібридів кукурудзи : Автореф. дис. ... канд. с.-г. наук : 06.01 .05 - Селекція рослин. - Дніпропетровськ, 2003. - 19 с.

3. Генетичний поліморфізм сомаклональних ліній кукурудзи, отриманих від лінії Р346 / Д. М. Майданюк, І. О. Андрєєв, К. В. Спірідонова, В. А. Кунах // Біополімери і клітина. - 2007. - Т. 23. № 4. - С. 324-331.

4. Деркач К. В. Калусогенний потенціал ліній кукурудзи групи Ланкастер в умовах in vitro / К. В. Деркач, О. Є. Абраімова, Т. М. Сатарова // Вісник Дніпропетр. ун-ту. Біологія. Екологія. -2011. - Вип. 19, т. 1. - С. 16-21.

5. Нові ранньостиглі та середньоранні самозапилені лінії плазми Ланкастер / Є. І. Бєліков, А. В. Алдошин, Т. Г. Купріченкова, С. О. Шевченко // Бюл. Ін-ту зернового господарства. - 2005. № 23-24. - C. 21-24.

6. Пиралов Г. Р. Особенности роста и дифференциации длительно пассируемой каллюсной культуры линии кукурузы ДК675 / Г. Р. Пиралов, О. Е. Абраимова // Физиология и биохимия культурных растений. -2000 . - Т. 35, № 5. - С. 372-376.

7. Пиралов Г. Р. Цитоморфологические особенности начальных этапов каллусогенеза и регенерации в культуре незрелых зародышей кукурузы / Г. Р. Пиралов, О. Е. Абраимова // Геном рослин: Зб. статей V Міжнар. конф. - Одеса, 2008. - С. 212-216.

8. Al-Naggar A. M. M. Plant regeneration of some Egyptian maize genotypes from type II callus maintained under water stress condition / A. M. M. Al-Naggar, A. I. Ragab, M. R. I. Al-Bakry // Arab Journal of Biotechnology. - 2011. - Vol. 14, N 1. - P. 49-60.

9. Callus induction and regeneration of elite Indian maize inbreds / A. Manivannan, J. Kaul, A. Singode, S. Dass // African Journal of Biotechnology. - 2010. - Vol. 9, N 44. - P. 7446-7452.

10. In vitro plant generation of tropical maize genotypes / A. H. Gorij, M. Zolnoori, A. Jamasbi, Z. Zolnoori // International Conference on Environmental, Biomedical and Biotechnology. - 2011. Vol. 16. - P. 52-59.

11. Multicellular genesis of leaf primordium was demonstrated via chimaeric transgenic plant of maize (Zea mays L.) regenerated from type II calli / Z.-Q. Xu, X. Huang, C. Feng et al. // Molecular Biology Reports. - 2010. - N 37. - P. 3525-3531.

Надійшла до редколегії 02.12.2011 